\title{
CARA PRAKTIS UNTUK SUKSES MEMBANGUN WIRAUSAHA PENDIDIKAN
}

\author{
FITRI MILASARI \\ Universitas Nahdlatul Ulama Sidoarjo
}

\section{Latar Belakang}

Ada banyak cara untuk memulai bisnis pendidikan tetapi untuk memulai bisnis yang berubah menjadi model bisnis yang sukses dan menghasilkan pendapatan profitabel adalah yang penting pada akhirnya. Pasar pendidikan asia khususnya Indonesia sangat besar dan jalan yang terbuka bagi pengusaha muda sangat besar. Memiliki ketajaman bisnis pendidikan yang tajam dan hasrat yang membara untuk berkembang adalah yang mendorong seorang wirausahawan untuk membuat kesuksesan mengelola wirausaha pendidikan di dunia yang kompetitif ini. Pendidikan Indonesia membutuhkan peningkatan akses, mutu dan relevansi pendidikan untuk memberi manfaat membangun bagi pendidikan dan rakyat Indonesia (Irawan et al., 2018). Implementasi teknologi pembelajaran di era industri 4.0 adalah salah satu cara yang diperlukan untuk menunjukkan kompetensi lulusan yang berkualitas (Sudrajat et al., 2019).

Dunia dan masyarakat membutuhkan kewirausahaan (Setyawati, Purnomo, Irawan, Tamyiz, \& Sutiksno, 2018). Dunia wirausaha menjadi trendi karena tampilan kesuksesan yang menyilaukan (Purnomo et al., 2019). Berikut beberapa cara praktis untuk sukses membangun suatu bisnis wirausaha pendidikan.

\section{Temukan audiens Anda}

Sekarang Anda punya ide yang lebih baik tentang seperti apa bisnis pendidikan Anda nantinya, saatnya untuk mulai membangun audiens. Langkah pertama di sini adalah fokus pada merek Anda. Anda harus memutuskan apakah Anda adalah produknya, atau apakah Anda ingin memulai sebuah platform untuk berbagai kursus yang lebih luas. Mungkin bijaksana pada titik ini untuk mempromosikan diri Anda sendiri, karena pengalaman dan keahlian Anda akan menjadi titik penjualan utama untuk kursus Anda. Anda selalu dapat beralih ke model yang lebih luas di kemudian hari, saat Anda memperluas dari hal-hal yang Anda ketahui ke kursus yang ditulis oleh orang lain. Merek pribadi juga akan membuat hidup Anda lebih mudah di media sosial. Orangorang dapat diam tentang terhubung dengan perusahaan, tetapi akan terlibat jauh lebih mudah dengan 'orang sungguhan'. Telusuri orang yang mungkin tertarik dengan program studi Anda - jika ini tentang menulis novel, maka cari novelis amatir; jika ini tentang teknik manajemen, cari manajer menengah. Ikuti mereka dan cari untuk bergabung dengan percakapan, serta bergabung dengan grup bisnis untuk pendidikan online dan area lokal Anda. YouTube adalah cara yang bagus untuk meningkatkan daya tarik kursus Anda dan mengarahkan lalu lintas ke situs Anda, seperti yang 
disebutkan sebelumnya, tetapi ada cara lain untuk memulai bisnis Anda. Jika Anda telah menulis panduan yang hebat, maka wajar untuk menganggap Anda seorang penulis yang sangat baik. Menulis konten berkualitas tinggi untuk blog di situs web Anda (dan menggunakan beberapa trik SEO) akan membantu situs web Anda muncul di mesin pencari, sementara mendekati situs web lain untuk menulisnya akan membantu menjadikan Anda sebagai nama tepercaya. Membangun otoritas dengan cara ini sangat penting, karena orang akan cenderung untuk google nama Anda untuk melihat apakah mereka dapat mempercayai kursus Anda. Jika mereka menemukan artikel yang Anda tulis di situs web tepercaya, ini akan meningkatkan legitimasi Anda. Pepatah lama bahwa 'jika Anda membangunnya, itu akan menjadi kenyataan' sebagian besar, tetapi orang-orang juga membutuhkan dorongan ke arah yang benar. Untuk bisnis yang dibangun di atas kredibilitas Anda sebagai guru, itu berarti membangun persona online yang memproyeksikan kredibilitas ini, dan memiliki kehadiran yang seluas dan meyakinkan mungkin (Eurostart Entreprises, 2015). Siswa perlu memahami apa yang diketahui dan apa yang diminta untuk memiliki kemampuan menjawab (Suci et al., 2018).

\section{Pilih Target Anda}

Langkah pertama adalah memutuskan target pasar orang yang ingin Anda ajar. Ini adalah sekelompok orang yang ingin mendaftar di sekolah Anda. Jika Anda sudah memiliki ide untuk suatu kursus, ada baiknya mencari siapa saja yang cocok untuk Anda. Target Anda dapat seluas industri, seperti desainer grafis. Atau bisa sempit, seperti dekorator kue di Jakarta. Mana yang paling cocok dengan keahlian Anda (Johnson, 2019). Penerapan pembelajaran multimedia dapat meningkatkan prestasi siswa; dan tes menunjukkan bahwa prestasi belajar siswa kelas belajar multimedia lebih baik daripada siswa kelas konvensional (Iskandar, Rizal, Kurniasih, Sutiksno, \& Purnomo, 2018).

Mengetahui siapa target pasarmu akan membuat ...

- memasarkan sekolah online Anda,

- merek platform sekolah online Anda,

- harga konten video atau biaya berlangganan Anda,

- dan membuat konten kursus.

\section{Pilih Investor Pertama dengan cermat}

Seperti yang kami katakan kesan pertama itu penting, itu juga berlaku untuk memilih investor pertama Anda. Startup pendidikan Anda harus mengikat investor yang kuat secara finansial tetapi juga mampu memberikan Anda dukungan pada masalah hukum dan teknologi. Ingat, startup Anda akan menghadapi tantangan di hari-hari awal. Hackeducation.com mengungkapkan bahwa banyak investor terkemuka telah menaruh uang mereka pada teknologi pendidikan. Jika investor pertama Anda dapat 
mengatasi masalah ini, bisnis pendidikan Anda dapat membuat langkah cepat dalam beberapa hari mendatang (Ray, 2015).

\section{Berdayakan tim}

Menyewa dan melatih staf, jika perlu, untuk membantu Anda menyediakan layanan dan produk untuk bisnis terkait pendidikan Anda (Brookins, 2019). Manajemen adalah proses mengarahkan atau menjalankan bisnis, serta. sekelompok manajer atau direktur (Purnomo, Putri, \& Rosyidah, 2017).

\section{Membiayai Bisnis}

Anda bisa mencari investor atau mengambil pinjaman dari bank. Itu tergantung pada jumlah uang yang bisa Anda keluarkan untuk bisnis Anda (Arya, 2019).

\section{Desainer}

Pekerjakan seorang desainer grafis dan desainer web untuk membuat materi pemasaran untuk bisnis wirausaha pendidikan Anda. Anda memerlukan logo yang mewakili produk atau layanan pendidikan yang akan Anda tawarkan. Anda juga memerlukan kartu nama, brosur, dan situs web (Brookins, 2019). Teknologi komputer telah menawarkan peluang baru dalam proses pembelajaran baik di ruang kelas, pembelajaran jarak jauh atau belajar mandiri (Simarmata et al., 2018).

\section{Penutup}

Cara praktis untuk sukses membangun suatu bisnis wirausaha pendidikan sebagai berikut: berdayakan tim, biayai bisnis, desainer, audien, investor dan target pasar.

\section{References}

Arya, N. (2019). Things to Consider While Starting an Educational Services Business. Retrieved December 16, 2019, from https://www.franchiseindia.com/education/thingsto-consider-while-starting-an-educational-services-business.12980

Brookins, M. (2019). How to Start an Education Related Small Business. Retrieved December 17, 2019, from https://smallbusiness.chron.com/start-education-relatedsmall-business-2239.html

Eurostart Entreprises. (2015). How to start an online education business. Retrieved December 18, 2019, from https://www.eurostartentreprises.com/businessadvice/item/194-how-to-start-an-online-education-business

Irawan, D. E., Purnomo, A., Sutiksno, D. U., Abraham, J., Alamsyah, A., Saputra, D. H., ... Rosyidah, E. (2018). Kajian Pendidikan Tinggi IDRI untuk DPR RI dan Ristek Dikti 2018. Bandung: ITB Press.

Iskandar, A., Rizal, M., Kurniasih, N., Sutiksno, D. U., \& Purnomo, A. (2018). The Effects of Multimedia Learning on Students Achievement in Terms of Cognitive Test Results. Journal of Physics: Conference Series, 1114(1), 012019. https://doi.org/10.1088/1742$6596 / 1114 / 1 / 012019$

Johnson, J. (2019). How to Start a Profitable Online School in 5 Easy Steps. Retrieved December 16, 2019, from https://www.uscreen.tv/blog/how-to-start-create-onlineschool/ 
Purnomo, A., Asitah, N., Rosyidah, E., Septianto, A., Daryanti, M. D., \& Firdaus, M. (2019). Generasi Z sebagai Generasi Wirausaha. https://doi.org/10.31227/osf.io/4m7kz

Purnomo, A., Putri, R. A., \& Rosyidah, E. (2017). Kamus Manajemen Sumber Daya Manusia. Sidoarjo: UNUSIDA Press.

Ray, H. (2015). 5 Easy Steps to Successfully Launch an Educational Startup. Retrieved December 18, 2019, from https://www.designhill.com/design-blog/easy-steps-tosuccessfully-launch-an-educational-startup/

Setyawati, I., Purnomo, A., Irawan, D. E., Tamyiz, M., \& Sutiksno, D. U. (2018). A Visual Trend of Literature on Ecopreneurship Research Overviewed within The Last two Decades. Journal of Entrepreneurship Education, 21(4), 1-7. Retrieved from https://www.abacademies.org/articles/a-visual-trend-of-literature-on-ecopreneurshipresearch-overviewed-within-the-last-two-decades-7468.html

Simarmata, J., Dharma, M., Putra Nasution, T., Manurung, R. T., Lubis, M. A., Kurniasih, N., ... Rahim, R. (2018). Prototype Application Multimedia Learning for Teaching Basic English. International Journal of Engineering \& Technology, 714(2), 264-266. https://doi.org/10.14419/ijet.v7i2.12.14689

Suci, S. H. A., Rosyidah, E., Asitah, N., Aini, N., Murni, A. W., Anam, F., ... Kuraesin, A. D. (2018). Learning from Picture and Picture Action Research : Enhancement of Counting Ability on Division of Numbers for Primary School Students. Journal of Physics: Conference Series, 1114(1), 012044. https://doi.org/10.1088/17426596/1114/1/012044

Sudrajat, D., Achdisty, M., Kurniasih, N., Roslina, Parwito, Mulyati, S., ... Sallu, S. (2019). The Implementation of Innovation in Educational Technology to Improve The Quality of Website Learning in Industrial Revolution Era 4.0 Using Waterfall Method. Journal of Physics: Conference Series, 1364, 012044. https://doi.org/10.1088/1742$6596 / 1364 / 1 / 012044$ 